\title{
居住地移動推移行列の特性変化把握手法に関する考察 A CONSIDERATION ON ANALYZING METHOD OF RELOCATION TRANSITION MATRIX CHANGE
}

\author{
石坂公一* \\ Koichi ISHIZAKA
}

The purpose of this paper is to develop an analyzing method of relocation transition matrix change, and to confirm the effectiveness of that method through application to actual data.

1. Transition matrix change can be broken roughly to 3 factors. Those are (1) Eigenvalue change,

(2) Eigenvector change, (3) the Compound effect of Eigenvalue and Eigenvector change.

2. In the case of relocation transition matrix change, these factors are interpreted as (1) Change of influence in the regional relocation sphere, (2) Change of the regional relocation sphere structure.

3. We applied this method to time series change of the relocation transition matrix in Tokyo metropolitan area, and confirmed the effectiveness of this method.

Keywords: Transition matrix, Analyzing method, Matrix change, Relocation, Eigenvalue, Eigenvector 推移行列、分析手法、行列変化、居住地移動、固有値、固有ベクトル

1.はじめに

近年、首都圈ではバブル崩壊以降の地侕の下落を背景として住宅 需要の「都心回帰」傾向が指摘されてきた。最近では都心部の人口 は回復に転じており、都心部の人口回復過程をミクロな地域レベル で詳細に分析した砳究 ${ }^{11} も$ 行われている。しかし、首都圈全域を対 象とした広域レベルでの世柿の居住地移動の構造がバブル以前と以 後でどのように変化したのかという点についての検討は未だ十分で はないと考えられる。また、居住地移動構造の変化の分析にあたっ ては、移動構造の特性と地価等の社会・経済的要因との関連性の分 析が重要であるが、そのためにはまず移動構造の特性を的確に把握 することが必要である。一般に居住地移動デー夕は地域間の移動世 帶数といら行列の形で得られるので、そのままでは広域に扝ける移 動構造の特性やその変化を把握することはそれほど容易ではない。 そこで本研究では、首都圈広域における世带の居住地移動構造の時 系列的な変化を社会 · 経済的要因と関連づけて分析するための基礎 として、居住地移動データから作成される推移行列（以下、居住地 移動推移行列という）の特性の変化を把握する手法を定式化すると ともに、これを用いて地俒バブルの影響を比較的強く受けたと思わ れる「新規持家入居世带」を対象にバブル以前と以後におけりる居住 地移動構造の特性の変化を見ていくことにしたい。
本砳觉で定式化した手法は、简単に畐えば、居住地移動推移行列 の特性を固有值と固有べクトルを通して把握しようとするものであ る。このような手法を採用したのは、後述するように、(1)固有值と 固有ベクトルは居住地移動推移行列が持つ特性の指標として解釈で きること、(2)推移行列を固有值と固有べクトルを用いて表現寸るこ とで、推移行列の特性の変化を固有值と固有ベクトルといら独立し たパラメータごとの変化分に分解して把握することが可能となるこ との 2 点に着目したためである。

2. 居住地移動推移行列の特性指標としての固有值と固有ベクトル 本章では、居住地移動推移行列の固有值と固有ベクトルが当該推 移行列の特性を把握するための指標として解釈できることについて 述べる。分析対象となる都市圈を $\mathrm{n}$ 個の地域に分割し、居住地移動 推移行列 Pの要素 $p_{1}$, を地域 $\mathrm{j}$ に居住していた世帯の地域 $\mathrm{i}$ への移 動確率（j 地域居住世帯の i 地域選択確率）と定義すると、Pは縦 ベクトルに左から作用する推移行列となり、 $p_{1}, \geqq 0 \quad[i, j=1 \sim n]$ 、 $\Sigma_{\mathrm{i}} \quad \mathrm{p}_{\mathrm{i} j}=1 \quad[\mathrm{j}=1 \sim n]$ となる。また、地域 $\mathrm{j} \rightarrow \mathrm{i}$ への移動世带数

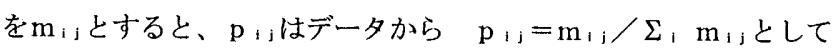
求められる。ここで、(1)Pの要素はすべて正である。(2)Pの固有值 はすべて異なる。(3)Pは実数の範困で刘角化可能である。 
ことを仮定し、Pの固有值を $1 、 \lambda_{2} \cdot \lambda_{n}$ 、対応する固有べクト ルをu〜期とすると以下が成り立つ。（ただし、U，以外の固 有ベクトルはノルムが 1 となるように基淮化して考える。)

(1)u，は各成分が正で列和が 1であるようにとれる。 (2) $\lambda_{2} \cdots \lambda_{n}$ の絶対值は 1 より小さい。

(3) $\mathrm{u}_{2} \cdots \mathrm{U}_{n}$ の列和は Oである。

(4) $u_{1} \cdot u_{n}$ は一次独立である

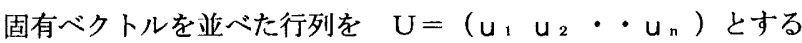
とUはn 次元空間のひとつの基底を与える。また、Uの逆行列を $\mathrm{V}=\mathrm{U}^{* 1}=\left\{\ell_{1}\right\}$ と寸ると、Vの第1行は各列とも 1 になる。ま た、PはVPUによって固有值からなる対角行列 $\Lambda$ に変換される。 すなわち $\mathrm{VPU}=\Lambda 、 \mathrm{P}=\mathrm{U} \Lambda \mathrm{V}$ であり、Pの特性を表現する パラメータは $\Lambda$ とUの要素として表現される。一方、自然基底

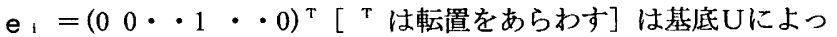
$\tau \mathrm{e}_{1}=\mathrm{u}_{1}+\ell_{21 \mathrm{u}_{2}}+\cdots+\ell_{n 1} \mathrm{u}_{n}$ とあらわされる。e、は Pによる変換を受けると、P e $e_{i}=u_{1}+\lambda_{2} \ell_{2} u_{2}+\cdots+$ $\lambda_{n} \ell_{n, u_{n}}$ となり、地域 $\mathrm{i}$ に居住していたという状態は確率的に 他の地域へも居住するという状態に変化することになる。ここで、 U、は列和が 1 であり、各e，に共通して含まれ、Pによる変換に 対して不変であることから、各地域に共通する基本的な地域選択確

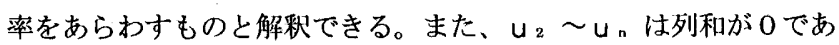
ることから、移動行動の面では地域間の相互流動の状況に刘応して おり、 $u_{j},[\mathrm{j}=2 \sim n]$ は、移動行動から見た場合のひとつの流動圈域 の構造をあらわしていると解釈できる。このもとで、 $e_{1}=u_{1}+$ $\ell_{21} \mathrm{u}_{2}+\cdot+\ell_{n} \mathrm{u}_{\mathrm{n}}$ の意味を考えると、当初の地域 $\mathrm{i}$ 居住世带 は各地域に共通した基本的な地域選択確摔をべースとして、各流動 圏域から も、の影響を受け、それらの影響がバランスした結果とし て地域 $\mathrm{i} に$ 居住していたと考えることができる。すなわち、も、は 地域 $\mathrm{i}$ 居住世帯が地域 $\mathrm{i}$ にとどまる場合を基淮とした流動圈域 $\mathrm{j} の$ 地域 $\mathrm{i}$ 居住世帯への影響力をあらわしており、その符号は影響力の 方向、絶対值は影響力の大きさをあらわすと解釈できる。ところで、 地域 $\mathrm{i}$ 居住世帯の移動行動の結果、e，はe， $\rightarrow \mathrm{P}$ e i に変化する。 この変化は $\mathrm{u},[\mathrm{j}=2 \sim \mathrm{n}]$ の係数が $\ell_{\mathrm{j}} \rightarrow \lambda ， \ell$, , となることによる ものであるから、e i $\rightarrow \mathrm{P} \mathrm{e} ，$ 変化は地域 $\mathrm{i}$ 居住世带に対する流

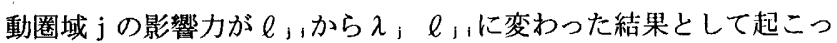

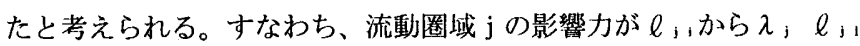
に変わったことでe，という状欵のバランスがくずれ、地域間移動 が発生し、P e 、という新たな状態に変化したと考えることができ る。一方、 $e_{1}-P_{e_{i}}=\left(1-\lambda_{2}\right) \ell_{21} u_{2}+\cdot+\left(1-\lambda_{n}\right) \ell_{n} u_{n}$ となるので、1ると考えられ、（1- $\lambda_{j} ） \ell$, の絶対値が大きいほど、流動圈域 $\mathrm{j}$ に関する影響力の変動は大きく、 $\mathrm{j}$ の構造に沿った地域間移動は活 発になることになる。

以上が、 $u ; \quad[j=2 \sim n] か ゙$ 移動行動の面での地域閒の相互流動の状 況をあらわしていると考えた場合の $\ell_{\mathrm{i}}$ 、入 $\lambda_{\mathrm{j}}$ の解釈であるが、u を移動した世帯の意識という面から解釈することも可能である。す なわち、世带は居住地選択に際して、意識中に地域間のトレードオ フ関係に関する構造を持っており、複数のトレードオフ関係を総合 的に評価した結果として、居住地の選択を行っていると考えること にすると、U，は世带の居住地選択における $\mathrm{j}$ 番目のトレードオフ
関係の構造を示していると解釈できる。この立場からは、 $e_{i}=u$ $+\ell_{2} i_{2}+\cdot+\ell_{n i u_{n}}$ は地域 $\mathrm{i}$ 居住世带が各地域に共通した基 本的な地域選択確率をべースとしてu ${ }_{j}$ で示される地域間トレード オフ関倸 $\mathrm{j}$ に地域 $\mathrm{i}$ 居住者に特有の重み

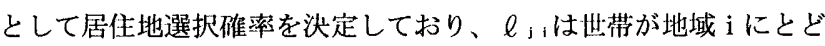
まる場合を基淮としたトレードオフ関係 $\mathrm{j}$ の重視度をあらわしてい ると考えられる。また、 $\mathrm{e} ， \rightarrow \mathrm{P}$ e，の変化は地域 $\mathrm{i}$ 居住世帯の地 域間トレードオフ関係の重視度が $\ell_{\mathrm{j} i} \rightarrow \lambda_{\mathrm{j}} \quad \ell_{\mathrm{j}}$ に変わったことで もたらされたと見ることができるので、1- 1 ， は j 番目のトレード オフ関係の重視度の変動率と解釈できる。

まとめると、居住地移動推移行列 Pの固有值、固有ベクトルおよ び固有ベクトルを並べた行列の逆行列の要素は、

(1) $\mathrm{u}$

: 各地域に共通寸る基本的な地域選択確率

(2) $\mathrm{u}$; $[\mathrm{j}=2 \sim \mathrm{n}]$ ：（行動面）流動圈域の構造

（意識面）地域閒のトレードオフ関倸

(3) $\ell_{\mathrm{i} i}$

$[j=2 \sim n]$

（行動面）地域 $\mathrm{i}$ 居住者に対する流動圈域 $\mathrm{j} の$

$[\mathrm{i}=1 \sim \mathrm{n}]$

影響力

（意識面）地域 i 居住者の地域間トレードオフ 関係 $\mathrm{j}$ の重視度

(4) $1-\lambda_{j}[j=2 \sim n]$ :（行動面）流動圈域 $\mathrm{j}$ の影響力の変動率

（意識面）地域間トレードオフ関係 $\mathrm{j}$ の重視度 の変動率

と考えることができ、居住地移動推移行列 Pの特性は、Pの固有值 と固有べクトルを用いてあらわすことができる。

\section{3. 居住地移動推移行列の要因分解}

本章では、 2 つの居住地移動推移行列 $\mathrm{P}$ と $\mathrm{P}+\Delta \mathrm{P}$ の差 $\Delta \mathrm{P}$ を前 章で整理した要因別に分解して把握することを考える。前述したよ うに、居住地移動推移行列の特性は固有值と固有ベクトルを用いて あらわすことができるので、 $\Delta \mathrm{P}$ を「固有值の差による部分」「固 有べクトルの差による部分」「㳹者の複合部分」に分解することで、 $P と \mathrm{P}+\Delta \mathrm{P}$ の特性の差を要因別に分解することができる。前章と 同様、(1) $\mathrm{P} 、 \mathrm{P}+\Delta \mathrm{P}$ ) 要素はすべて正である。(2) $\mathrm{P} 、 \mathrm{P}+\Delta \mathrm{P}$ の 固有值は寸べて暴なる。(3) P、P $+\Delta P$ は実数の範囲で対觕化可能 である。ことを仮定し、P+ $\mathrm{P} P$ の固有值からなる行列を $\Lambda+$ $\Delta \Lambda$ 、固有ベクトルからなる行列を $U+\Delta U 、 U+\Delta U$ U逆行列を $\mathrm{V}+\Delta \mathrm{V}$ とすると、

$\mathrm{P}+\Delta \mathrm{P}=(\mathrm{U}+\Delta \mathrm{U}) \quad(\Lambda+\Delta \Lambda) \quad(\mathrm{V}+\Delta \mathrm{V})$ であり、

$\Delta \mathrm{P}=\mathrm{U} \Delta \Lambda \mathrm{V}$ : 固有値変化の一次分

$+\Delta U \Lambda V+U \Lambda \Delta V$ : 固有ベクトル変化の一次分

$+\Delta U \Delta \Lambda \mathrm{V}+\mathrm{U} \Delta \Lambda \Delta \mathrm{V}$ : 固有值と固有ベクトル変化の複合效果

$+\Delta U \Lambda \Delta V \quad:$ 固有心゙クトル変化の二次分

$+\Delta U \Delta \Lambda \Delta V$ : 固有值と固有ベクトル変化の二次複合 效果

となる。詳細は付録で記述しているが、 $\Delta \mathrm{V} は$ は固有ベクトル変化の 直接效果分と複合效果分に分解寸ることが可能であるので、推移行 列の差 $\Delta \mathrm{P}$ は、大きくは「固有值であらわされる流動圈域（もしく は地域間トレードオフ関係）の変動率の差の直接效果分」「固有心 クトルであらわされる基本的な地域選択確率および流動圈域（もし くは地域間トレードオフ関係）の構造の差の直接效果分」「その他 

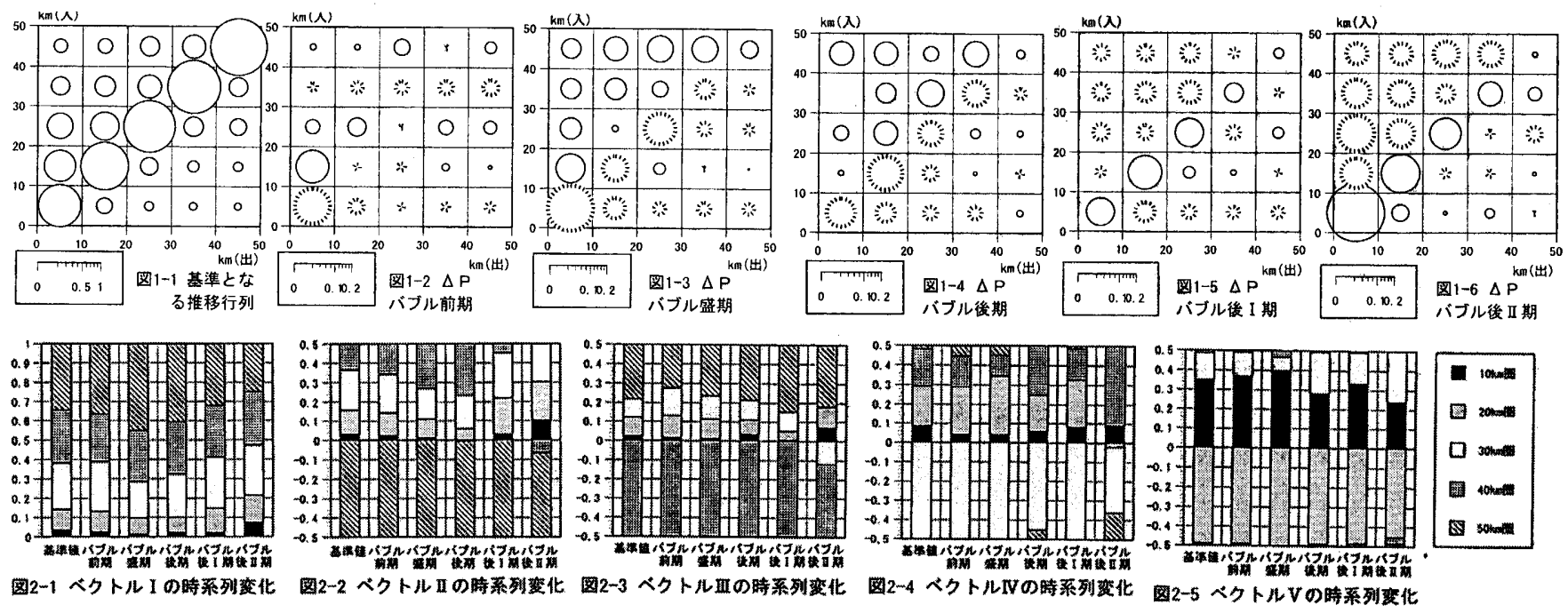
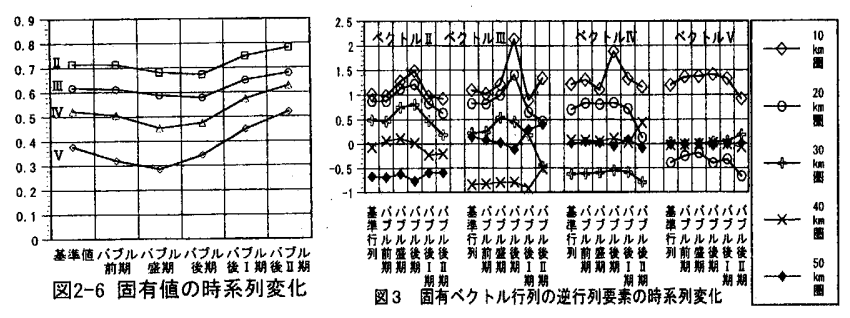

の複合効果分」の 3 つに分解して把握することができる。前 2 者は さらに固有值ごと、固有べクトルごとに細分することができる。

\section{4.「新規持家取得世带」の居住地移動特性の時系列変化}

本章では、前章までに定式化した方法を用いて首都圈で「新規に 持家に入居した世帯（持家以外から持家に入居した世帯）」を対象 として、バブル期をはさむ期間における居住地移動推移行列の特性 の時系列的な変化を分析することにする。対象地域は首都50km圈で あり、地域区分は「 $10 \mathrm{~km}$ 圈」「20km圈」「30km圈」「40km圈」「50 $\mathrm{km}$ 圈」の5つ、入居時期は「1984〜1988年（バブル前期）」「1989 〜1991年 (バブル盛期)」「1992 1993年（バブル後期）」「1994 〜1996年（バブル後 I 期）」「1997〜1998年（バブル後 II 期）」の 5 時点である ${ }^{2)}$ 。分析にあたっては基準となる推移行列 $\mathrm{P}$ を設定す る必要があるが、ここでは期間を通じての平均的な像を基準行列と して用いることを意図して、各期の推移行列の「相乗平均」を基淮 行列 $\mathrm{P}$ とした。具体的には、各期のデータから得られる推移行列 $\mathrm{P} i$ $\sim \mathrm{P}_{5}$ から $\mathrm{Q}=\mathrm{P}_{1} \mathrm{P}_{2} \mathrm{P}_{3} \mathrm{P}_{4} \mathrm{P}_{5}$ を計算し、Qの固有值行列 $\Lambda$ と固有べクト ル行列Uを求めた後、 $\Lambda$ の要素を $1 / 5$ 乗し、 $U \Lambda^{1 / 5} U^{-1}$ にって $\mathrm{P}$ を求めた。したがって、基準となる行列の固有值行列は $\Lambda^{1 / 5}$ 固 有ベクトルはU、固有ベクトルの逆行列は $V=U^{-1 て ゙ あ る 。 な お ~}$ 以下では、固有值については一次の直接效果そのもの、固有べクト ルについては一次と二次の直接効果を合計したものをそれぞれ、固 有值変化の直接效果、固有べクトル変化の直接效果ということにし、 その他の複合効果をすべて合計したものを交差効果と呼ぶことにす る。また、交差效果はまとめて 1 つの要因と考えることにする。 4-1. 居住地移動推移行列の変化

基準となる推移行列 $\mathrm{P}$ と $\Delta \mathrm{P}_{1}\left(=\mathrm{P}_{1}-\mathrm{P}\right) \sim \Delta \mathrm{P}_{5}\left(=\mathrm{P}_{5}-\mathrm{P}\right)$ を図 1 に示 す。なお図中の破線の円は負の值をあらわしている。図より居住地 移動は基本的には同一圈域内での移動が多く、30km圈以遠ではこの 傾向が顕著であることがわかる。また、時系列的な変化を見ると、 バブル前期には10km圈からの移動で平均に比べて圈内移動の割合が 少なく、 $10 \mathrm{~km} \rightarrow 20 \mathrm{~km}$ 圈の割合が多い等、 $10 \mathrm{~km} 、 20 \mathrm{~km}$ 圈からの移動で やや遠隔化の傾问が見られるが、30km圈以遠からの移動では平均と の差はほとんどなく、20km圈以内からの移動以外では移動先の遠隔 化はそれほど進展していない。しかし、バブル盛期になると $20 \mathrm{~km} 〜$ $40 \mathrm{~km}$ 圈でも圈内移動の割合は少なくなるとともに遠隔化の傾同が强 くなる。バブル後期でもこの傾向には基本的に変化はないが、遠隔 化はやや緩和する兆しが見られ、バブル後 I 期になると10４0km圈 では $20 \mathrm{~km}$ 圈を中心として圈内移動の割合が多くなるとともに遠隔化 の割合は平均よりもやや少なくなる。バブル後 II 期になると同一圈 内移動の割合はさらに多くなり、特に10km圈からの移動でこの傾问 が顕著となるとともにより遠い距離带への移動割合は大幅に減少す る。これから、新規持家入居世鱼の居住地移動行動は、バブルの発 生につれてまず都心地域から相対的な遠隔化が始まり、この傾向が 次第に郊外部に波及していき、バブルの終舃とともに同一图内率の 上昇という形で遠隔化傾向がおさまるという経緯をたどってきたと 言える。

4-2. 推移行列の固有值、固有ベクトルの変化

図 2 に $\mathrm{P}_{1} \sim \mathrm{P}_{5}$ の固有ベクトルを付録で述べる方法によって $\mathrm{P}$ の固 有ベクトルに刘応づけた結果を示す。なお、比較を容易にするため 各固有べクトルは成分の絶対值の和が 1 となるように調整して表示 してある。また、図 3 には各距潅带における固有ベクトル行列の逆 行列の要素（恒等的に 1 となる固有べクトルIに対応寸る要素は除 く）の時系列変化の状況を示す。以下では、各固有值、固有べクト ルを基淮となる推移行列における固有值の大きい順に固有值 $\mathrm{I} \sim \mathrm{V}$ 、 ベクトル I 〜とと呼ぶことにする。

(1) ベクトルIの時系列変化

前述したように、ベクトル I は各時点における基本的な地域選択 確率をあらわしている。時系列的な変化を見ると、バブル前期から バブル盛期にかけては $30 \mathrm{~km}$ 圈以内の割合が低下し、40km圈以遠（特 に $50 \mathrm{~km}$ 圈）が増加したが、バブル後期以降は $30 \mathrm{~km}$ 圈内の割合が增加 に転じるとともに $50 \mathrm{~km}$ 圈は継続して娍少している。また、バブル後 II 期では $20 \mathrm{~km}$ 圈以内（特に $10 \mathrm{~km}$ 圈）の割合の増加が目立っている。 
これから新規持家入居世帯の基本的な地域選択確摔はバブル期には 大幅に郊外化したが、バブル後はバブル前の水淮以上に都心型とな り、中でも $10 \mathrm{~km}$ 圈は移動先地域としての比重を増加させたと言える。 (2) ベクトル II の時系列変化

ベクトル II は成分の状況から基本的には、行動面では50km圈を中 心とした遠郊部とその他の地域との間の相互流動をあらわす軸であ り、意識面では遠郊部とその他の地域との間のトレードオフ関係を あらわす軸であると解釈できる。また、成分の符号が反転する点が 各時点における行動上、意識上の遠郊地域の境界に対応していると 考えられる。時系列的な変化を見ると、バブル前期〜後期にかけて は50km圈のみが遠郊地域であり、その他地域における $40 \mathrm{~km}$ 圈の比重 が継続的に増大するとともに $20 \mathrm{~km}$ 圈以内の比重の低下が見られ、流 動圈域の範囲の遠隔化が進行したが、バブル後はその他地域におうけ る30km圈以内の比重が増加し、バブル後 II 期では $40 \mathrm{~km}$ 圈の符号が負 に転ずる等、ベクトルII で示される流動圈域はバブル前期以上に都 心よりに移動してきたと言える。また、ベクトル II の影響力は $30 \mathrm{~km}$ 圈以内ではバブル前期〜後期にかけて增加した後、減少に転じてお り、バブル後は $50 \mathrm{~km}$ 圈を中心とする遠郊部とその他の地域との間の 流動圈域の影響は $30 \mathrm{~km}$ 圈内の地域に関してはしだいに弱まってきた と蓄える。

(3) ベクトルIII の時系列変化

ベクトルIIIは成分の状況から、行動面では遠郊部のひとつ内側の 地域を中心とした流動圈域をあらわす刺であり、意識面では当硋地 域と遠郊部およびより内側の地域との閒のトレードオフ関係を示し ていると考えられる。成分の時系列的な変化を見ると、バブル前期 〜バブル後 I期までの間は符号が負となるのは40km圈のみで女り、 正の符号を持つ地域内での $20 \mathrm{~km}$ 圈内の比重の低下と $50 \mathrm{~km}$ 圈の比重の 增加が進行したが、バブル後 II 期になると $30 \mathrm{~km}$ 圈の符号が負に転じ るとともに正の符号地域内での $20 \mathrm{~km}$ 圈内の比重の増加が見られる。 このことから、バブル前期〜バブル後 I 期までは遠郊部のひとつ内 側の地域は40km圈であり、主として50km圈との間で流動圈域を棈成 していたが、バブル後 II 期になると $30 \mathrm{~km}$ 圈もこの流動圈域に含まれ るようになり、20km圈内との流動の比重も増川してきたと言える。 これは、ベクトルIIの場合に見られた $50 \mathrm{~km}$ 圈を中心とした流動圈域 の範囲がバブル後 II 期には都心よりに移動したことと符合しており、 ベクトル III で示される遠郊部のひとつ内側の地域を中心とする流動 圈域もまた都心よりに移動したと言える。このことは、ベクトル III の影響力が $20 \mathrm{~km}$ 圈内ではベクトル II の場合と同様にバブル後期をピ 一クとして減少する傾问にあること、およびバブル後II 期になると $30 \mathrm{~km}$ 圈に対する影響力の符号が反転していることによっても示され ている。

(4) ベクトルIVの時系列変化

ベクトルIVはベクトルIIT゙あらわされる流動圈域よりもさらにひ とつ内側の $30 \mathrm{~km}$ 圈を中心とした流動圈域をあらわす軸であると考え られる。時系列的な変化を見ると、流動圈域の構造は、バブル前期 〜盛期の間は主として $20 \mathrm{~km}$ 圈と $30 \mathrm{~km}$ 圈との閒の流動が中心であった が、バブル後期には $40 \mathrm{~km}$ 圈の比重が増加した後、バブル後 I 期には また以前の状態に戻り、バブル後II 期になるともっぱら $30 \mathrm{~km}$ 圈と 40 $\mathrm{km}$ 圏との間の相互流動をあらわすものへと変化している。 $30 \mathrm{~km}$ 圈を 中心とした流動圈域の範国は、バブル期の遠隔化とバブル後 I 期の
$20 \mathrm{~km}$ 圈倒への回帰を経て、バブル後 II 期には $30 \mathrm{~km}$ 圈と $40 \mathrm{~km}$ 圏相互閒 というより狭いものへと性格を変化させてきたと言えよう。意識面 から見れば、 $30 \mathrm{~km}$ 圈はバブル前期〜盛期までは主として $20 \mathrm{~km}$ 圈との トレードオフ関係の中でとらえられてきたが、バブル後期になると $40 \mathrm{~km}$ 圈との対比でとらえられる傾问が強くなり、バブル後 I 期には また以前の状態に戻り、バブル後 II 期になると $20 \mathrm{~km}$ 圈ではなく、40 $\mathrm{km}$ 圈との対比地域としての性格が明確になったと言える。また、影 響力の時系列変化を見ると、10km圈ではベクトル II 、III と同様の傾 问を示寸が、20〜40km圈ではバブル後 II 期には $20 \mathrm{~km}$ 圈への影響力が ほとんどなくなり、代わって $30 \mathrm{~km}$ 圈、40 km圏で影響力が増加すると いら上述した性格の変化を反咉した動きが見られる。

(5) ベクトルVの時系列変化

ベクトルVは、成分の状㳇から主として20km圈を中心とした流動 圈域をあらわす軸であると考えられる。時系列的な変化を見ると、 バブル前期〜盛期にかけては $10 \mathrm{~km} /$ 圈と $20 \mathrm{~km}$ 圈の間の流動が支配的で むつたが、バブル後期になると $30 \mathrm{~km}$ 圈の比重が增加し、バブル後 I 期にはやや戻した後、バブル後 II 期にはまた $30 \mathrm{~km}$ 圈の比重が增加す るように変化している。バブル前期〜バブル後 I 期までの変化は、 ベクトルIVの場合と同様に流動圈域の郊外よりべの移動と都心より への回㷌に対応しており、バブル後 II 期における $30 \mathrm{~km}$ 圈成分の增加 は、20km圈を中心とする流動圈域がそれまでの $10 \mathrm{~km}$ 圈との間の流動 を中心としたものから $30 \mathrm{~km}$ 圈をも含むもの一と変化したことの反映 と考えられる。このことは影響力の変化にもあらわれており、バブ ル後 II 期には $10 \mathrm{~km}$ 圈への影響力は低下しているのに対し、20km圈、 $30 \mathrm{~km}$ 圈への影響力はそれほど大きくはないが増玑している。これは、 バブル後 11 期にはベクトルIVの性格が $30 \mathrm{~km}$ 圈と $40 \mathrm{~km}$ 圈の相互流動と いう比較的狭い流動圈域を示寸ものに変化したため、それまでべク トルIVで表現されていた $20 \mathrm{~km}$ 圈と $30 \mathrm{~km}$ 圈との相互流動がベクトルV であらわされるようになったためであると考えられる。

(6) 固有値の時系列変化

ベクトル II V Vに刘态する固有值の時系列的な変化を見ると、固 有值IV とVはバブル前期〜盛期にかけて低下、バブル後期以降は増 加、固有值 II 、IIIはバブル前期〜後期までは微減、その後は增加と いう経過をたどっている。これから各流動圈域の影響力の変動率は、 バブル期には地域間移動が活発になる力向に変化した後、バブル後 はそれが鎮静化するという経緯をたどってきたと言える。また、固 有值の変化幅は固有值IVとVの方が II 、III よりも大きく、バブルの 影響は都心よりの地域を中心とした流動圈域の影響力の変動の変化 により㺈くあらわれている。ただ、各べクトルに刘㐫する固有值の 大きさの順序には変わりはなく、バブル前後で流動圈域の影響力（ もしくは地域間トレードオフ関係の重視度）の変動摔には構造的な 変化は見られなかった。すなわち、各期とも変動摔は「50km圈中心 の流動圈域」 $\rightarrow\lceil 40 \mathrm{~km}$ 圈中心の圈域」 $\rightarrow\lceil 30 \mathrm{~km}$ 圈中心の圈域」 $\rightarrow \Gamma$ $20 \mathrm{~km}$ 圈中心の圈域」の順に大きくなっており、流動圈域の中心が都 心部になるにつれて、その圈域の構造に沿った移動が起こりやすい という状況に基本的な変化はなかったと言える。 4-3. 居住地移動推移行列の時系列変化の要因分解

本節では、上記のような推移行列の固有值、固有べクトルの変化 が実際の推移行列の変化にどのように反映されたかについて見てい くことにする。要因分解は固有嗔別、ベクトル別に可能であるが、 

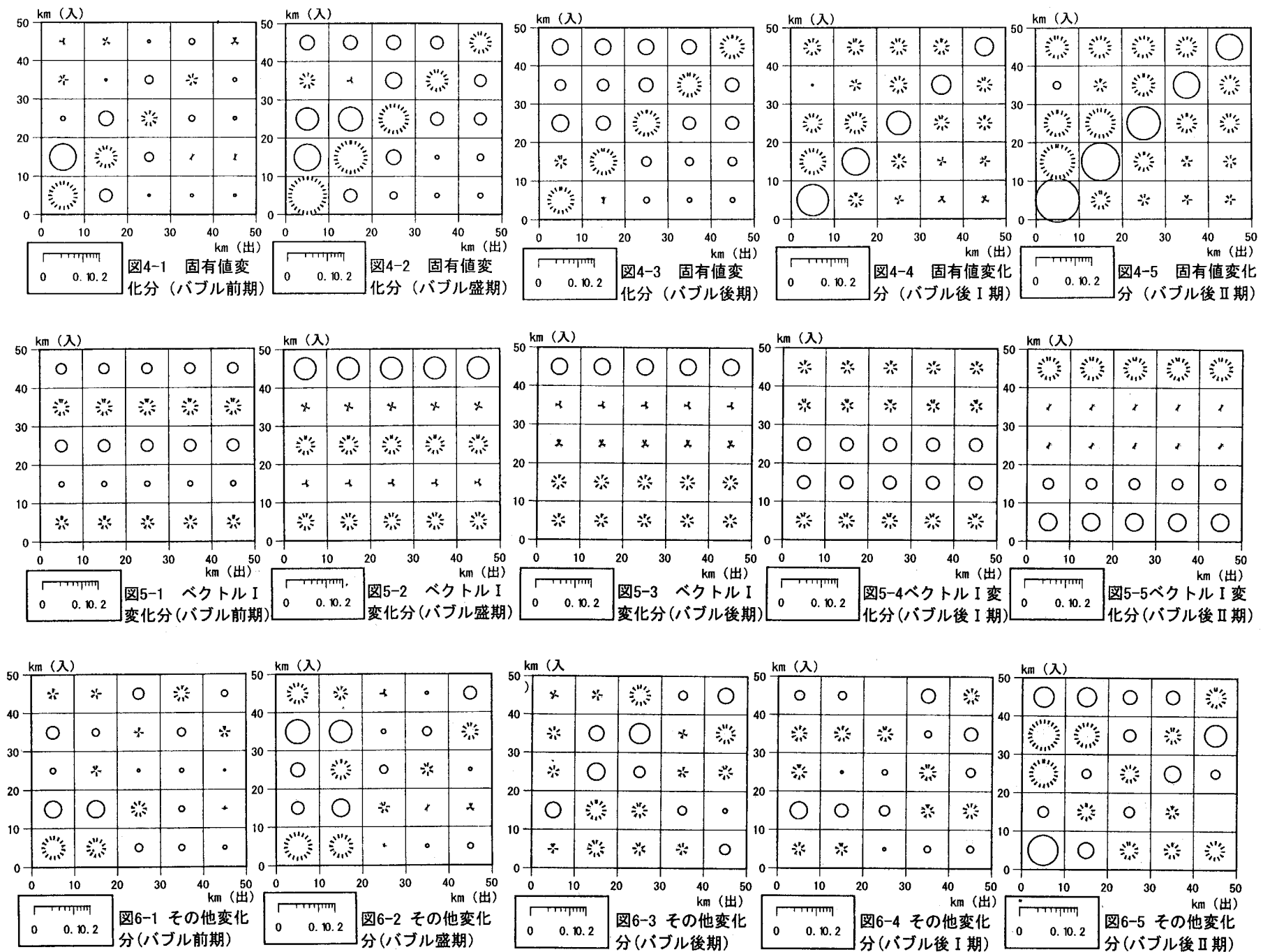

要因を「固有值の変化分」「基本的な地域選扷確率の変化分」「そ の他のベクトルの変化分＋交差效果分」の 3 つに大別し、図 1 の場 合と同様に、基淮となる推移行列との差を図示したものが図 $4 \sim 6$ である。図 1 と図 4 と比べてみると、推移行列変化のおおむねの傾 向は固有值の変化分で表現されており、推移行列の構造変化は、固 有值の変化分のみである程度までの把挃が可能であると言える。し かし、バブル前期〜後期にかけての壹隔化の進展傾向等、表現が十 分ではない部分もある。一方、図 5 は地域に共通する基本的な地域 選択確摔の変化の影響を見たものであり、バブル期における遠隔化 の進展とバブル後の都心よりへの回㷌は見や寸い形で表現されてい るが、地域別の特性については当然のことながら表現されていない。

図 6 は図 1 のうち、図 4、5で表現しきれていない主として流動 圈域（もしくは地域間トレードオフ関係）の構造変化による分を示 したものである。図 4 と図 6 をあわせて見るとバブル前期におろける $10 \mathrm{~km}$ 圈から $20 \mathrm{~km}$ 圈への流出割合の増加、バブル盛期の $10 \mathrm{~km} 、 20 \mathrm{~km}$ 圈 からの移動における移動先の遠隔化、バブル後期の遠隔化傾向の30 $\mathrm{km}$ 圈への波及、バブル後の $10 \mathrm{~km}$ 圈からの流出率の顕著な減少といっ た居住地移動推移行列の変化は、固有値の変化による分に流動圈域

（もしくは地域間トレードオフ関係）の構造変化による分がおおむ ね同方向に重ね合わされた結果としてあらわれたと言える。 4-4. 流出率の要因分解
次に、各圈域から別の圈域に移動した世带の割合 (流出率) の時 系列変化について、各固有值、ベクトルの変化分別に見ていくこと にする。図 7 は各地域からの流出率の変化を各固有値、固有べクト ルの変化分別に分解して示したものであり、正の值は基淮となる行 列と比較した場合の流出増加、負の值は流出減少をあらわしている。 図より $50 \mathrm{~km}$ 圈以外の圈域では、バブル前期〜後期では全体として流 出増加であったものがバブル後は流出減少に転じており、特にバブ ル後II期における減少幅が大きいことがわかる。地域別には $10 \mathrm{~km}$ 圈 における変化が最も大きい。要因別には各地域とも固有值の変化に よる分が支配的であり、10km圈では固有值 $\mathrm{V}$ の、20km圈では固有值 VとIV、30km圈では固有值IV、40km圈では固有值III、50kn圈では固 有値II の変化による影響が大きくなっている。すなわち、当然では あるが、各地域とも流出率は当該地域の比重が大きい流動圈域にお ける変動率の変化の影響を強く受ける傾向がある。

一方、固有ベクトルの変化の影響は全体としては固有值変化の影 響ほど大きくはなく、交差効果による緩和が見られる場合もある。

ベクトル I の変化による影響は $50 \mathrm{~km}$ 圏では比較的大きいものの他 の地域ではそれほどではなく、基本的な地域選択確率の変化の影響 は50km圈以外ではあまり大きくはなかったと言える。

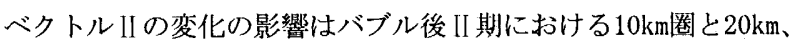
$30 \mathrm{~km}$ 圈、バブル盛期〜後期における50km圈で比較的大きい。 $50 \mathrm{~km}$ 圈 


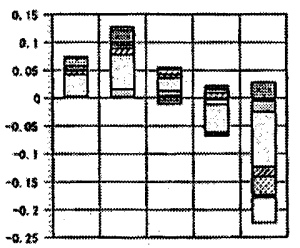

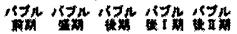

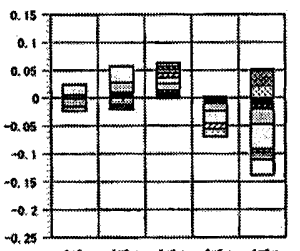

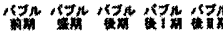

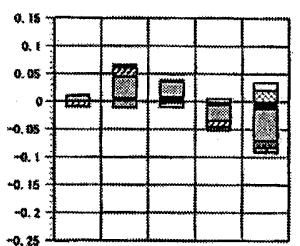

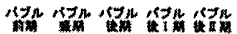

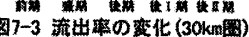

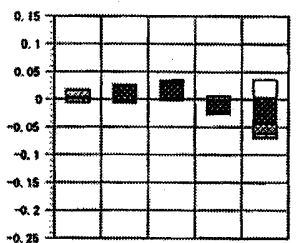

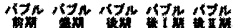

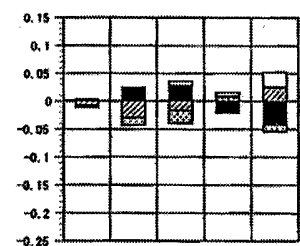

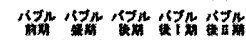

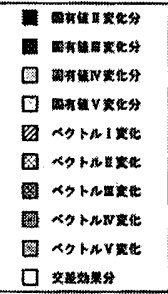

とその他地域との流動をあらわすべクトルII のバブル期における郊 外部の成分の増加は、 $10 \mathrm{~km} 、 20 \mathrm{~km}$ 圈からの流出を増加させ、 $50 \mathrm{~km}$ 圈 からの流出を減少させる方向で作用したが、バブル後は $10 \mathrm{~km}$ 圈の成 分の増加にともない、バブル後 I 期における $20 \mathrm{~km}$ 圈での流出率減少 への作用を経て、バブル後 II 期には $20 \mathrm{~km} 、 30 \mathrm{~km}$ 圈でも流出増加、10 $\mathrm{km}$ 圈での流出減少の方向に作用するように変化した。ただ、20km圈 と $50 \mathrm{~km}$ 圈では交差効果はベクトル II の作用と逆方向に作用しており、 ベクトル II の影響はあまり明確なものとはなっていない。

ベクトルII は40km圈を中心とした流動圈域を示す軸であるが、そ の変化の影響はバブル後 I 期までは各地域ともほとんど見られない。 バブル後 II 期になると $20 \mathrm{~km}$ 圈での流出増加と $30 \mathrm{~km} 、 40 \mathrm{~km}$ 圈での流出 減少方向への作用が若干見られるが、各地域とも逆力向の交差効果 があるので、実際上は流出率変化へのベクトルIIIの変化の影響はほ とんど見られなかったと言えよう。

ベクトルIVは30km圈を中心とした流動圈域を示す軸であるが、そ の変化の影響は $10 \mathrm{~km} 、 20 \mathrm{~km}$ 圈からの流出の場合に大きく、変化の方 向は10km圈では期間をとおして流出增加、20km、30km圈では流出減 少の方向である。図は省略するがベクトルIVの変化の影響を推移行 列の要素ごとに見ると、バブル前期〜盛期とバブル後 II 期では $30 \mathrm{~km}$ 圈以外の地域では $10 \mathrm{~km} 、 30 \mathrm{~km} 、 50 \mathrm{~km}$ 圈の割合の減少と $20 \mathrm{~km} 、 40 \mathrm{~km}$ 圈 の割合の増加、30km圈ではその逆の方向となっており、30km圈を中 心とした流動圈域のバブル期における $40 \mathrm{~km}$ 圈側への移動 $\rightarrow 20 \mathrm{~km}$ 圈侧 一の回帰 $\rightarrow 30 \mathrm{~km}$ 圈と $40 \mathrm{~km}$ 圈相互閒流動という変化は、いずれも他地 域からの移動先としての $20 \mathrm{~km} 、 40 \mathrm{~km}$ 圈の割合を增扗させる力向で作 用したと言える。また、ベクトルVについては、比較的時系列的な 変化が小さいので、その変化の影響はほとんど見られない。

以上をまとめると、各地域からの流出率の時系列的な変化のかな りの部分は固有值で示される各流動圈域の影響力の変動率の変化に よるものであり、固有ベクトルの変化であらわされる基本的な地域 選択確摔および流動圈域（もしくは地域間のトレードオフ関保）の 構造変化による分は相対的にそれほど大きくはなかったと言えよう。

\section{5.まとめ}

本硚觉では、「居住地移動行動の特性把握」という観点から居住 地移動推移行列の固有值と固有べクトルの解釈を行うとともに、居 住地移動推移行列の変化を固有値変化分、固有ベクトルの変化分お よび交差効果分に分解して把握する方法を提案した。また、それを 用いてバブル前期からバブル後にいたる間の首都50 $\mathrm{km}$ 圈における「 新規持家入居世帯」の居住地移動行動の変化の分析を行った。得ら れた結果をまとめると以下のようになる。

(1)居住地移動推移行列の固有値と固有べクトルは、「(1)固有値 1 に 対応する固有ベクトル＝基本的な地域選択確率」「(2) それ以外の固 有ベクトル＝流動圈域（もしくは居住地選択における地域閒のトレ
一ドオフの関係) の構造」「(3) 1 以外の固有值=詨応寸る固有ベク トルで示される流動圈域の影響力（もしくは対応寸る地域閒トレー ドオフ関係の重視度）の变動率」と解釈することができる。

(2)居住地移動推移行列の変化は、大きくは「流動圈域の影響力（も しくは地域間トレードオフ関係の重視度）の変動率の変化分」「基 本的な地域選択確率の変化分」「流動圈域（もしくは地域閒トレー ドオフ関係）の構造变化分」「交差効果分」に分解して把握するこ とができる。

(3)バブル前期からバブル後までの間の「新規持家入居世带」に㧍け る「都心地域からの移動における移動先の相対的な遠隔化の進行」

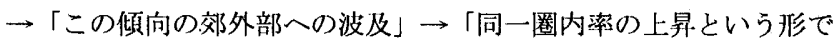
の遠隔化傾问の鎮静化」とい5居住地移動行動の変化は、「流動圈 域の影響力の変動率の変化による分」「基本的な地域選択確率の変 化による分」「流動圈域の構造変化による分」の3つの要因がおお む水同方向に作用することによってもたらされ、3つの要因のうち では固有值で示される「変動摔の変化」による分の影響が最も大き かったと言える。

今後の課題としては、より多くのデータに本砸究で提案した方法 を適用することによってその有效性と限界を昒確にすること、およ び得られた要因別の変化傾向と地仙等の社会・経济的な状況をあら わ寸指標との関連性を分析すること等が挙げられる。

\section{付録 居住地選択推移行列の差の要因分解}

ここでは、 $2 つ の$ 居住地移動推移行列 $\mathrm{P}$ と $\mathrm{P}+\Delta \mathrm{P}$ の差 $\Delta \mathrm{P}$ を 3 章で整理した要因別に分解して把握する方法について詳述する。

(1) $\Delta \Lambda$ の細分

3 章における仮定(3)により、 $\Delta \Lambda$ は対角行列で、 $(1,1)$ 要素は 0 、 $(i, i)$ 要素 $[i=2 \sim n]$ は $\Delta \lambda$ ，となるので、 $\Delta \Lambda$ ，を $(i, i)$ 要素が $\Delta \lambda$ ，で他の要素は0であるような行列とすれば、 $\Lambda=\Sigma ， \Delta \Lambda$ ， で、U $\Delta \Lambda \mathrm{V}$ は、U $\left(\Delta \Lambda_{2}+\cdots+\Delta \Lambda_{n}\right) \mathrm{V}$ と各固有值ごとに 分解される。

(2) $\Delta \mathrm{U} \Lambda \mathrm{V}+\mathrm{U} \Lambda \Delta \mathrm{V}$ の細分

$\mathrm{P}$ の固有ベクトルu， $[\mathrm{i}=1 \sim \mathrm{n}]$ に対応する $\mathrm{P}+\Delta \mathrm{P}$ の固有べクト ルを $u_{4}+\Delta u_{1}$ とすると、 $\Delta u_{1}$ はP 固有ベクトルを用いて、 $\Delta u_{1}=\alpha_{11} u_{1}+\alpha_{21} u_{2}+\cdots+\alpha_{n 1} u_{n}$ とあらわすことがで きるが、 $\Delta u ， の$ 列和が 0であることから $\quad \alpha_{11}=0$ となる。す なわち、 $\Delta U=\left(\Delta U_{i}, \Delta U_{2} \cdot \Delta U_{n}\right)$ は、係数行列Aを $\left\{\alpha_{i j}\right\}$ とすれば、 $\Delta \mathrm{U}=\mathrm{UA}$ となり、 $\mathrm{A}$ は $\mathrm{A}=\mathrm{V} \Delta \mathrm{U}$ で求められる。

また、 $(\mathrm{V}+\Delta \mathrm{V})(\mathrm{U}+\Delta \mathrm{U})=\mathrm{I} 、(\mathrm{I}+\mathrm{A}) \quad{ }^{1}(\mathrm{I}+\mathrm{\Lambda})=\mathrm{I}$ の関係より、 $\Delta \mathrm{V}$ は $\Delta V=\left\{(\mathrm{I}+\Lambda)^{-1}-\mathrm{I}\right\} \mathrm{V}$ となるので、固有ベクトルからなる行 列の逆行列の差 $\Delta V$ は $\Delta U$ UをUであらわした場合の係数行列 $\mathrm{A}$ を用 いてあらわすことができる。（I+A）“の要素を $\left\{\mathrm{b}_{1},\right\}$ とすると、 以下が成り立つ。 
(1) $\Delta u_{1} \sim \Delta u_{n}$ の值に関わらず、 $b_{11}=1 、 b_{1 j}=0 \quad[j=2 \sim n]$ (2) $(\mathrm{I}+\mathrm{A})^{-1}$ の第 1列については、

(a) $\Delta u_{1}=0$ のときは、 $\Delta u_{2} \sim \Delta u_{n}$ の值に関わらず、 $b_{11}=0$ $[\mathrm{i}=2 \sim \mathrm{n}]$

(b) $\Delta u_{1} \neq 0 、 \Delta u_{j}=0 \quad[j=2 \sim n]$ の時は $b_{11}=-\alpha_{11} \quad[i=2 \sim n]$ となる。これから $(\mathrm{I}+\mathrm{A})^{-1}$ の第 1 列は $\Delta \mathrm{u}_{\text {、 }}$ に関係する量であって、 $\Delta u_{1}$ のみによる差 $\left(-\alpha n_{1}\right)$ と $\Delta u_{1} と \Delta u_{2} \sim \Delta u_{n}$ の複合効 果によって生ずる差に分解できる。すなわち、 $(\mathrm{I}+\mathrm{A})^{-1}$ の第 1 列の $(1,1)$ 要素は $1 、(i, 1)$ 要素は、複合効果分を $\beta$;, と才ば、 $\mathrm{b}_{11}=-\alpha_{11}+\beta_{11} \quad[\mathrm{i}=2 \sim \mathrm{n}] \quad$ と書くことができ、 $\Delta \mathrm{u}_{1}=0$ のと きは複合効果分も 0 となる。

(3) $(I+\Lambda) ~ ' の$ 第 $\mathrm{j}$ 列 $[\mathrm{j}=2 \sim n]$ については、

(a) $\Delta u_{j}=0$ のときは、 $b_{i 1}=0 \quad[i=1 \sim n]$

(b) $\Delta \mathrm{u}_{\mathrm{j}} \neq 0, \Delta \mathrm{u}_{2}=\cdot=\Delta \mathrm{u}_{1,1}=\Delta \mathrm{u}_{\mathrm{j}+1}=\cdot=\Delta \mathrm{u}_{\mathrm{n}}=0$

のときは $\mathrm{b}_{\mathrm{ij}}=-\alpha_{\mathrm{i} j} /\left(1+\alpha_{\mathrm{j},}\right) \quad[\mathrm{i}=2 \sim \mathrm{n} 、 \mathrm{i} \neq \mathrm{j}]$

$$
\mathrm{b}_{\mathrm{j} j}=1 /\left(1+\alpha_{\mathrm{ij}}\right)
$$

(c) $\Delta u_{1}$ は $\quad b_{1}, \quad[i=2 \sim n] \quad$ の値に関係しない。

となるので、 $(I+\Lambda)$ の第 $\mathrm{j}$ 列 $[\mathrm{j}=2 \sim \mathrm{n}]$ は、複合効果分を $\beta_{\mathrm{i}}$ ， とすれば、 $(1, j)$ 要素は $0 、(i, j)$ 要素 $[i=2 \sim n]$ は

$\mathrm{b}_{\mathrm{ij}}=-\alpha_{\mathrm{ij}} /\left(1+\alpha_{\mathrm{j} j}\right)+\beta_{\mathrm{ij}} \quad[\mathrm{i} \neq \mathrm{j}]$

$\mathrm{b}_{\mathrm{j},}=1 /\left(1+\alpha_{\mathrm{j} j}\right)+\beta_{\mathrm{i}}[\mathrm{i}=\mathrm{j}] \quad$ と書くことがで きて、いずれも右辺の第 1 項は $\Delta u_{j}$ ，值接效果分、第 2 項は $\Delta u_{j}$ と $\Delta u_{2} \sim \Delta u_{n}\left[\Delta u_{j}\right.$ を除く $]$ との複合効果分をあらわす。 以上より、 $(\mathrm{I}+\mathrm{A}))^{-1}-\mathrm{I} \quad$ O $(\mathrm{i}, \mathrm{j})$ 要素 $[\mathrm{i}=1 \sim \mathrm{n}, \mathrm{j}=1 \sim \mathrm{n}]$ は $\left\{-\alpha_{i j} /\left(1+\alpha_{j j}\right)+\beta_{i j}\right\} \quad$ と $\Delta u_{i}$ の直接效果分と複合効 果分の和の形であらわすことができる。なお、 $\alpha_{1 \mathrm{j}}=\beta_{1 \mathrm{j}}=0$

$[\mathrm{j}=1 \sim n]$ である。すなわち、(I+A)) -1-I の第 $\mathrm{j}$ 列は $\Delta \mathrm{u}_{\mathrm{j}}$ に起 因する量であり、第 1 項は $\Delta u ;$ の直接効果分、第 2 項は $\Delta u j$ と $\Delta u_{k}(k \neq j)$ の複合效果分となる。また、 $\Delta u_{1}$ の影響は第 1 列以 外には及ばない。

固有ベクトルの差の一次分 $\Delta U \Lambda \mathrm{V}+\mathrm{U} \Lambda \Delta \mathrm{V}$ は $\Delta \mathrm{U} \Lambda \mathrm{V}+\mathrm{U} \Lambda \Delta \mathrm{V}=\mathrm{UA} \Lambda \mathrm{V}+\mathrm{U} \Lambda\left\{(\mathrm{I}+\Lambda){ }^{1}-\mathrm{I}\right\} \mathrm{V}$ $=\mathrm{U}\left\{\mathrm{A} \Lambda+\Lambda\left[(\mathrm{I}+\Lambda)^{-1}-\mathrm{I}\right]\right\} \mathrm{V}$

であり、A $\Lambda+\Lambda\left\{(I+A)^{11}-I\right\}$ の $(1, j)$ 要素 $[j=1 \sim n]$ は 0 、

$(i, j)$ 要素 $[i=2 \sim n, j=1 \sim n]$ は

$\lambda_{j} \alpha_{i j}+\lambda_{1}\left\{-\alpha_{i j} /\left(1+\alpha_{i j}\right)+\beta_{i j}\right\}$

$=\alpha_{i j}\left\{\lambda_{j}-\lambda_{i} /\left(1+\alpha_{i j}\right)\right\}+\lambda_{i} \beta_{i j}$

となるので、 $\Delta \mathrm{U} \Lambda \mathrm{V}+\mathrm{U} \Lambda \Delta \mathrm{V}$ は固有べクトルごとに差の直接効 果分と差の間の複合効果分に分解することができる。なお、 $\lambda_{1}=1$ である。また、 $\Delta U \Delta \Lambda \mathrm{V}+\mathrm{U} \Delta \Lambda \Delta \mathrm{V}$ （固有值、固有ベクトル変 化の複合效果) についても、上記において $\Lambda \rightarrow \Delta \Lambda$ とすることによ 、って同様の手順で各要素を求めることができる。

(3) $\Delta \mathrm{U} \Lambda \mathrm{VV}$ について

固有ベクトル変化の二次分 $\Delta U \Lambda \Delta V$ は、Aを用いた表現では $\mathrm{UA} \Lambda\left\{(\mathrm{I}+\mathrm{A})^{-1}-\mathrm{I}\right\} \mathrm{V}$ となる。 $\mathrm{A} \Lambda\left\{(\mathrm{I}+\mathrm{\Lambda})^{-1}-\mathrm{I}\right\}$ の $(1, \mathrm{j})$ 要素 $[\mathrm{j}=1 \sim \mathrm{n}]$ は $0 、(i, j)$ 要素 $[\mathrm{i}=2 \sim \mathrm{n}, \mathrm{j}=1 \sim \mathrm{n}]$ は

$\sum_{k} \lambda_{k} \alpha_{i k}\left\{-\alpha_{k j} /\left(1+\alpha_{j j}\right)+\beta_{k j}\right\} \quad[k=2 \sim n]$ となり、第 $\mathrm{j}$ 列 $[\mathrm{j}=1 \sim n]$ は $\Delta \mathrm{u},=0$ の時は 0 となる。また、第 $\mathrm{j}$ 列 $[j=2 \sim n]$ のち、 $\left\{-\lambda_{1} \alpha_{i j}{ }^{2} /\left(1+\alpha_{j j}\right)\right\} \quad[i=2 \sim n]$ は $\Delta u ，$ のによって決まる量であり、 $\Delta u ，$ の直接效果の二次分
とみなせる。（ $\Delta u_{1}$ については二次分は 0 となる。）

すなわち、固有ベクトル変化の二次分 $\Delta U \Lambda \Delta V$ Vついても固有 ベクトル変化の直接効果分と複合効果分に分解することができる。 $\Delta \mathrm{U} \Delta \Lambda \Delta \mathrm{V}$ についても同様である。

(4) $\Delta P$ の詳細分解

以上をまとめると、

$\Delta \mathrm{P}=\mathrm{U} \Delta \Lambda \mathrm{V}+\Delta \mathrm{U} \Lambda \mathrm{V}+\mathrm{U} \Lambda \Delta \mathrm{V}+\Delta \mathrm{U} \Delta \Lambda \mathrm{V}+\mathrm{U} \Delta \Lambda \Delta \mathrm{V}$ $+\Delta U \Lambda \Delta V+\Delta U \Delta \Lambda \Delta V$

$=\mathrm{U}\left\{\Delta \Lambda+\mathrm{A} \Lambda+\Lambda\left[(\mathrm{I}+\Lambda)^{1}-\mathrm{I}\right]+\mathrm{A} \Delta \Lambda+\Delta \Lambda\left[(\mathrm{I}+\mathrm{A})^{\prime}-\mathrm{I}\right]\right.$ $\left.+\mathrm{A} \Lambda\left[(\mathrm{I}+\mathrm{A})^{-1}-\mathrm{I}\right]+\mathrm{A} \Delta \Lambda\left[(\mathrm{I}+\mathrm{A})^{-1}-\mathrm{I}\right]\right\} \mathrm{V}$

の右辺のUとVではさまれた部分の要素は、

$(1, j)$ 要素 $[j=1 \sim n]$ については各要因分とも 0

$(i, 1)$ 要素 $[i=2 \sim n]$ については

$\Delta \Lambda_{1} \quad \Delta U_{1}{ }_{1}$ の直接效果分 $\Delta U_{1}, \varepsilon \Delta U_{｝ ， \text { の複合効果分 }$ $[U \Delta \Lambda \mathrm{V}] \quad[\Delta \mathrm{U} \Lambda \mathrm{V}+\mathrm{U} \Lambda \Delta \mathrm{V}] \quad[\Delta \mathrm{U} \Lambda \mathrm{V}+\mathrm{U} \Lambda \Delta \mathrm{V}]$

$$
0+\left(1-\lambda_{1}\right) \alpha_{i 1}+\lambda_{i} \beta_{11}
$$
$\left[\begin{array}{c}\Delta u_{1} \text { と } \Delta \mathrm{u}, \text { の複合効果分 } \\ {[\Delta U \Lambda \Delta V]}\end{array}\right]\left[\begin{array}{c}\Delta u_{1} \text { と } \Delta \lambda, \text { の複合効果分 } \\ {[\Delta U \Delta \Lambda V+U \Delta \Lambda \Delta V]}\end{array}\right]$

$\Delta \lambda_{i} \alpha_{i 1}$

$\Sigma_{k} \lambda_{k} \alpha_{1 k}\left(-\alpha_{k 1}+\beta_{k 1}\right)$

$[\mathrm{k}=2 \sim \mathrm{n}]$

$\Delta u_{1} 、 \Delta u_{1} 、 \Delta \lambda$, の複合 $)\left(\Delta u_{1} 、 \Delta u_{1} 、 \Delta \lambda\right.$, の 効果 $[\Delta U \Delta \Lambda V+U \Delta \Lambda \Delta V]$ 複合効果分 $[\Delta U \Delta \Lambda \Delta V]$ $\Delta \lambda_{1} \beta_{11}+\sum_{k} \Delta \lambda_{k} \alpha_{i k}\left(-\alpha_{k 1}+\beta_{k 1}\right)$ $[\mathrm{k}=2 \sim \mathrm{n}]$

$(i, j)$ 要素 $[i=2 \sim n, j=2 \sim n]$ については

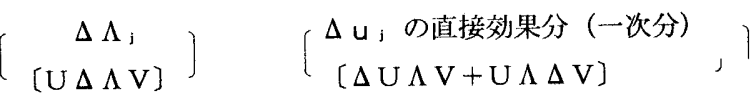

$\Delta \lambda_{j}[\mathrm{i}=\mathrm{j}]+\alpha_{\mathrm{ij}}\left\{\lambda_{\mathrm{j}}-\lambda_{\mathrm{i}} /\left(1+\alpha_{\mathrm{j}}\right)\right\}$

$0 \quad[\quad i \neq j]$

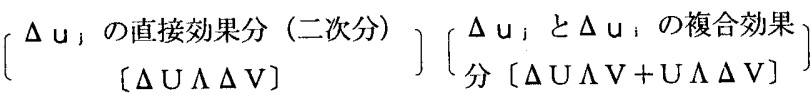

$-\lambda_{i} \alpha_{i j}^{2} /\left(1+\alpha_{j j}\right)+\lambda_{i} \beta_{i j}$

$\Delta u$, と $\Delta u ，$ の複合效果分 $[\Delta U \Lambda \Delta V]$

$(\Delta U \Lambda \Delta V$ から $\Delta u ，$ の直接效果の二次分を除いたもの)

$\sum_{k} \lambda_{k} \alpha_{2 k}\left(-\alpha_{k j}+\beta_{k j}\right)$

$[\mathrm{k}=2 \sim \mathrm{n}]$

$\left(\Delta u_{\mathrm{j}}\right.$ と $\Delta \lambda$, の複合效果分

$[\Delta \mathrm{U} \Delta \Lambda \mathrm{V}+\mathrm{U} \Delta \Lambda \Delta \mathrm{V}]$ $\Delta u_{1}, \Delta u_{i} 、 \Delta \lambda_{1}$, 複合効果 $[\Delta U \Delta \Lambda \mathrm{V}+\mathrm{U} \Delta \Lambda \Delta \mathrm{V}$ $\alpha_{i j}\left\{\Delta \lambda_{1}-\Delta \lambda_{1} /\left(1+\alpha_{j\}}\right)\right\}+\Delta \lambda_{1} \dot{\beta}_{1 j}$ $\left(\Delta u_{1} 、 \Delta u_{1} 、 \Delta \lambda\right.$, の複合効果分 $\left.[\Delta U \Delta \Lambda \Delta V]\right)$

$\Sigma_{\mathrm{k}} \Delta \lambda_{\mathrm{k}} \alpha_{\mathrm{ik}}\left\{-\alpha_{\mathrm{kj}} /\left(1+\alpha_{\mathrm{j} j}\right)+\beta_{\mathrm{kj}}\right\} \quad[\mathrm{k}=2 \sim \mathrm{n}]$ となる。

以上より、居住地移動推移行列 $\mathrm{P}$ と $\mathrm{P}+\Delta \mathrm{P}$ について、固有值と 固有ベクトルを求め、固有べクトル閣の対忘づけを行うことによっ

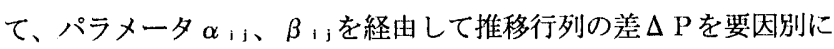
分解することが可能となる。

ところで、 $\Delta \mathrm{P}$ の右辺のUとVではさまれた部分の要因 $\mathrm{k}$ に対応 する部分を $\Gamma^{k}$ とすると、 $\Gamma^{k}$ もしくは複数要因の部分和 $\Gamma^{k 1}+$ ・ ・+ $\Gamma^{\mathrm{k}}$ に右からVを乘じた行列は当該要因（もしくは部分和を構 成する複数要因）による固有べクトルからなる座標軸Uにおける座 
標の変化分をあらわす。また、これにさらに右からUを乗じたもの は各要因による自然基底上での変化をあらわすことになる。このこ とから要因別の影響力をあまり詳しく把握する必要がない場合には、 対象とする要因についてのみ $\mathrm{P}+\Delta \mathrm{P}$ のパラメータを求め、その他 の要因に関してはV $\Delta \mathrm{PUT゙}$ 求められる行列から対象とする要因分 の影響力を除けば得られることになる。たとえば要因を大きく「各 地域に共通する基本的な地域選択確率の変化」と「それ以外の変化 」に分けて把握したい場合には、比較刘象の推移行列 $\mathrm{P}+\Delta \mathrm{P}$ に関 しては固有值 1 に対忘する固有ベクトルのみを求めれば良く、他の 固有值、固有べクトルを求める必要はない。また、要因を「基本的 選択確率の変化」「固有值の変化」「その他の変化」に分けて把握 したい場合には、「固有值 1 に刘応する固有ベクトル」と「固有値」 だけを求めれば良いことになる。

（5）居住地移動推移行列が複素固有值を持つ場合

これまでは理論的な検討を容易にするため、 $\mathrm{P} と \mathrm{P}+\Delta \mathrm{P}$ は実数 の範囲で対角化可能であることを仮定してきた。しかし、実際は推 移行列の固有方程式が複素根を持つ場合が存在する。このため、本 節では推移行列に関する仮定「(3) P、P $+\Delta \mathrm{P}$ は実数の範囲で刘㑲 化可能である。」を緩和し、複素固有值が存在する場合について検 討しておく。ただし、仮定(1)、(2)は引き続き成り立つものとする。 この場合、複素固有值に対応寸る固有べクトルは複素ベクトルとな るが、固有ベクトルの実部と虚部を別々の実ベクトルと考えると実 根に対忘する固有ベクトルを含めた固有ベクトル全体は $\mathrm{n}$ 次元哭間 の基底を構成する。複素固有ベクトルの実部、虚部に対応する実べ クトルを $U_{1} 、 U_{1} 11$ としUi、 、 $U_{i+1}$ を含む基底を $U 、 V=U^{-1}$

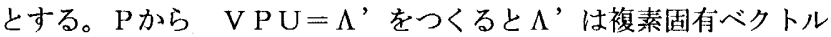
の実部、虚部に対忘する固有べクトルの籄所に複素固有值の実部 $\lambda$ ， 虛部士 $\gamma$ ，の值が入ったものとなる。

$\mathrm{V}=\left\{\ell_{1 ;}\right\}$ とすると、自然基底 e；はPによる変換を受けると

$\mathrm{Pe}_{\mathrm{j}}=\mathrm{u}_{1}+\lambda_{2} \ell_{2 \mathrm{j}} \mathrm{u}_{2}+\cdots \cdot \cdot+\lambda_{1}, \ell_{1,1, \mathrm{j}} \mathrm{u}_{1,1}$ $+\left(\lambda_{1} \ell_{11}+\gamma_{1} \ell_{1,1, j}\right) u_{1}$

$+\left(-\gamma_{1} \ell_{1 j}+\lambda_{1} \ell_{1,1, j}\right) u_{1,1}+\cdots+\lambda_{n} \ell_{n j} u_{n}$ となる。流動圈域の影響力の変動は、固有估が実数となるものにつ いては、 $\lambda_{2} \sim \lambda_{n}$ であらわされるが、固有値が複素数となるもの については

$\left(\lambda_{1} \ell_{i j}+\gamma_{1} \ell_{1,1, j}\right) / \ell_{1 j}=\lambda_{1}+\gamma_{1} \quad\left(\ell_{i+1, j} / \ell_{i j}\right)$ $\left(-\gamma_{1} \ell_{1 j}+\lambda_{1} \ell_{1+1, j}\right) / \ell_{11, j}=\lambda_{1}-\gamma_{1}\left(\ell_{i j} / \ell_{1+1, j}\right)$ となって、2つの流動圈域の影響力は刘になって変化することにな る。ただ、この場合でも、右辺をそれぞれ、 $\lambda^{\prime}{ }^{j} ， 、 \lambda^{\prime} j^{j}+1$

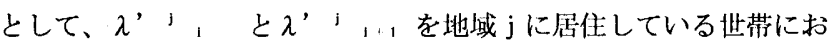
けるい,とu $1+1$ であらわされる流動圈域の影響力の変動の指標と

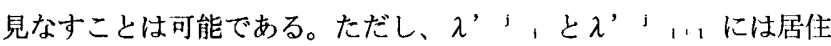
している地域特性をあらわす 複素固有べクトルに対态する流動圈域に関してはその影響力の変動 率は地域によって翼なることになる。ただ、実際のデータでは複素 固有值が存在する場合でもその虚部の值は 0 に近いことが多いので、 $\ell_{i+1, j} / \ell_{i j} 、 \ell_{i j} / \ell_{i+1, j}$ の值にもよるが複素根の虚部の值 の影響力はあまり問題にならないことが多いと考えられる。

また、Pと $\mathrm{P}+\Delta \mathrm{P}$ の要因分解に際しては、 $\Lambda$ おび $\Delta \Lambda$ が対角 行列であることは積極的には利用していないので、複素固有值があ
る場合でも形式的には $\Delta P$ の要因分解は可能である。ただし、この 場合、 $\Delta \Lambda$ ，は対角要素のみではなく、行ごとに考える必要がある。 (6) その他

以上により、 $\Delta \mathrm{P}$ の右辺のUと Vではさまれた部分は要因別に分 解することができ、表現基底をUから自然基底に変換する（左から $\mathrm{U}$ 、右からVをかける）ことで $\Delta \mathrm{P}$ そのものを要因別に分解するこ とができる。ただ、実際上は解䐆が容易な結果を得るためには $\mathrm{P}$ と $\mathrm{P}+\Delta \mathrm{P}$ の固有ベクトル間の刘态関係が適切に把握されている必要 がある。固有值 1 に対応するべクトル閒の対応関倸については問題 ないが、その他の固有ベクトル閒の対态関係は必ずしも自明ではな い。もし、対応関係づけが適切でないと各要因別の結果の和には問 題はないものの要因別には変化分の絶対值が無意味に大きくなって しまうことがあり得る。国有べクトル閒の対态づけの適切さは「複 合效果による変化分の絶対值の総和をできるだけ小さくする」とい う規淮で一応は評価できると思われるが、可能な対応づけの場合の 数は(n-1)!だけあるのでnがある程度以上になるとすべての組み合 わせを計算することは困難となる。このため本㼋究では「u，に対 忘させる固有べクトルui $+\Delta u_{1}$ は $u_{i}$ に最も近いもの $\left(\Delta u_{1}\right.$ のノルムが最も小さいもの）を選ぶ」という規準で作成した固有心゙ クトル間の対応づけを初期值として、このまわりで固有べクトル間 の対忘づけを逐次的に変化させて複合效果に起因する変化分の絶対 值の総和が最小となるような組み合わせを選ぶという方法で固有心゙ クトル閒の対态づけを行っている。

ところで、ここでの $\Delta \mathrm{P}$ の要因分解法は、 $\mathrm{P}$ と $\mathrm{P}+\Delta \mathrm{P}$ の固有値 と固有べクトルの差を基礎にしたものであるため、これらが安定的 に求められることが前提となっている。一般に推移行列の要素の変 動が小さい場合でも固有值や固有べクトルの変動は大きくなる可能 性があるので、ここで定式化した方法を適用するためには $\mathrm{P} と \mathrm{P}+$ $\Delta P$ は十分に安定的である必要がある。 $P$ と $P+\Delta P$ は居住地を移 転した圮漢数のデータから算出せざるを得ないことを考えると、こ のことはPと $\mathrm{P}+\Delta \mathrm{P}$ を算出するもととなったデータが十分なサン プル数を有している必要があることを意味している。

注

1) 中山学、大江守之：東京都心地域における人口回復過程からみた居住構造の 変容に関す石师究、都林計画論文集、第38-3号、pp49-54、2003年10月 2) 居住地移動データは、1988、1993、1998年の住宅統計調査（都书整储公団に よる特別集計を含む) より作成した。

参考文献

1)石圾公一：土地利用遷移行列の分析手法に関卞る考察--首都圈市街化区域に おける住居系用途を中心とした土地利朋変化動问の分析 その1一、日本建 築学会計画系論文集、第436 号、pp59-69、1992年 6 月

2) 長谷川洋、石坂公一：昭和59 63年の閒の居住地移動からみた首都圈の圈域 構造一大都市圈に扔ける居住地移動に関寸る研究 その 1 -、日本建築学会 計画系論文集、第493 号、pp215-222、1997年 3 月

3)石坂公一、長谷川洋：首都圈における圈内移転汿場情造の時系列変化一大都 市圈に括ける居住地移動に関する破究 その 2 -、日本建築学会計画系諭文 集、第521 号、pp245-252、1999年 7 月

（2004年 6 月28日原稿受理，2005年 4 月28日採用決定） 